\title{
Curve Sagittal Mentoplasty, Description of the Technique and Evaluation of the Neurosensory Response. Case Series
}

\author{
Mastranzo Corona Héctor ${ }^{1}$, Carrillo Rivera Jorge Arnulfo ${ }^{2}$, Salazar Jiménez Marcos Irving \\ $\mathrm{MD}^{3}$, Ortíz Héctor Martínez $\mathrm{MD}^{4}$, Tolentino Gonzalez Christian Stefan MD², Martínez \\ Moctezuma Alan $\mathrm{MD}^{3}$, Andrea Fernandez Cervera $\mathrm{MD}^{5}$, Fierro Reyez Mario $\mathrm{MD}^{6}$, Medina \\ Andrade Luis Angel MD ${ }^{6}$, Garcia Diaz Edson Antonio MD $^{6}$, Flores Rodriguez Daniel MD', \\ Heftye Sanchez Brandon $\mathrm{MD}^{8}$ \\ ${ }^{1}$ Oral and maxilofacial surgeon, High Speciality Hospital Centenario de la Revolución Mexicana”, Morelos, \\ Mexico. ISSSTE \\ ${ }^{2}$ Oral and maxilofacial surgeon, General Hospital “Dr. Darío Fernández Fierro” Mexico city. ISSSTE. Private \\ practice. \\ ${ }^{3}$ General Surgery Service, Hospital Central Norte de Petroleos Mexicanos, Mexico City, Mexico \\ ${ }^{4}$ General Surgery Service, Hospital Regional de Alta Especialidad del Bajio, Guanajuato, Mexico \\ ${ }^{5}$ Otorrinolaringology Resident, Centro Medico ISSEMYM Arturo Montiel Rojas, Mexico \\ ${ }^{6}$ General Surgery Service, Hospital General de Zona $1{ }^{a}$ Rdolofo Antonio de Mucha Macias, Mexico City, \\ Mexico \\ ${ }^{7}$ Plastic Surgery Service, Hospital 20 de Noviembre, ISSSTE, Mexico City, Mexico \\ ${ }^{8}$ General Surgery Service, Hospital Español de México, Mexico City, Mexico
}

*Corresponding Author: Dr. Jorge Arnulfo Carrillo Rivera. Dental and Maxilofacial Rehabilitation, Consultory 124. Av. Juárez Núm. 8 Col. Las Margaritas, Tlalnepantla Estado de México. Tel 53618677. E-mail: : dr_jorge_carrillo_cmf@hotmail.com

Abstract: Described in 2006 by Wang and Cols.m the sagittal curve mentoplasty is defined as the semilunar osteotomy realized in the thinnest section of the parasymphysis to reduce the risk of postoperative neurosensory lesions in the soft tissue during the treatment of mild to moderate microgeny.

Materials and Methods: It was a prospective study to evaluate the neurosensory response to touch, thermal stimulus and the motor function at first and sixth month after surgery in 7 patients with sagital modified curve mentoplasty between January and March 2014, in the High Speciality Hospital Centenario de la Revolución Mexicana and Dario Fernande Fierro Hospital, ISSSTE.

Results: All patients referred their satisfaction with the procedure. From the 7 patients, 3 mentions that in the sensibility test to touch they had a transient deficiency, 2 in the right side and 1 in the left side, and this problem improves after the first month after surgery. At temperature test 5 mention diminished thermal perception and 2 mentions a normal perception at the second month. In the motor response, none of the seven patients referred abnormal changes.

Conclusions: The sagittal modified curve mentoplasty diminish significantly the neurosensorial complications because is performed according to the chin anatomy, using as a reference point the thinnest jaw border, the incision is smaller, manipulation is far from the mental nerve and does not require the dislocation of the mylohyoid muscle.

Keywords: Saggital modified curve mentoplasty, mentoplasty, neurosensorial response, Neurosensory disturbance, Sagittal curve osteotomy

\section{INTRODUCTION}

The sagittal curved osteotomy was described for the correction of mild to moderate microgenesis by a minimally invasive approach, using like the anatomic reference for the osteotomy the thinner point of the mandibular parasymphysis and respecting the insertion of the mylohyoid muscle. 1,2 . 
For the evaluation of the thinner and thicker point of the mental symphysis a two dimension cephalometry is performed, with an anteriorposterior and vertical view $\mathrm{w}^{3,4,5}$.

\section{Surgical Procedure}

Previous to general anaesthesia the surgical marking is performed indicating the medial face line, tip of the nose (NT), lower edge of the vermillion (LEV), mental point (MP) and the thinner point of the parasymphysis (TPP) according to the previous lateral and panoramic cephalometry (Fig. 1-6).

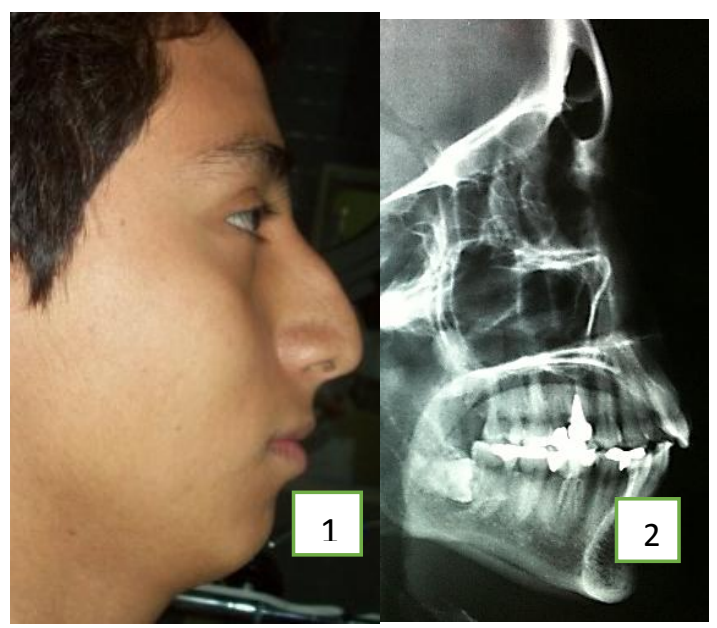

Figures 1\&2. 1.The initial lateral aspect of the patient. 2. Lateral view $x$-ray

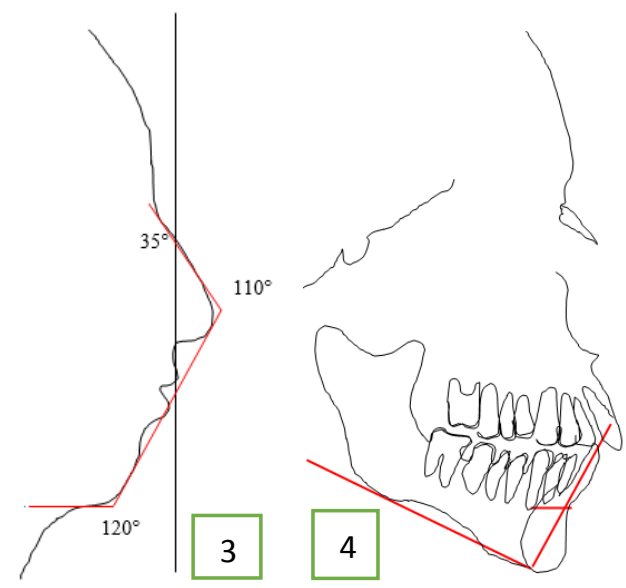

Figures 3\&4. Cephalometry of soft and hard tissues

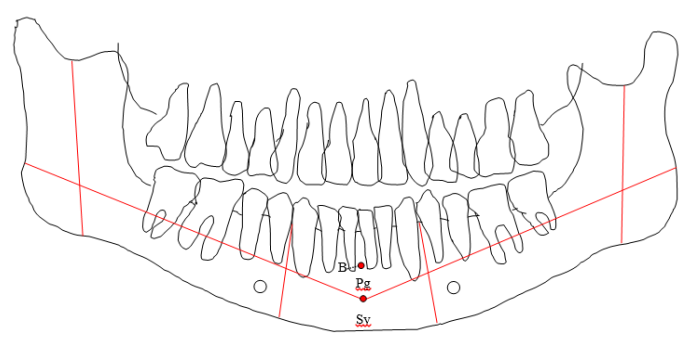

Figure 5. Panoramic cephalometry

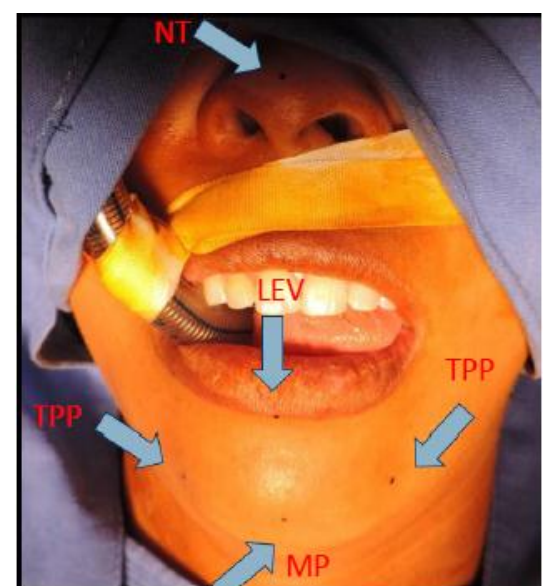

Figure 6. Anatomic references marking. Tip of the nose (NT), the lower edge of the vermillion ( $L E V)$, mental point (MP) and the thinner point of the parasymphysis $(T P P)$

Under general anesthesia and orotracheal intubation, the initial approach is by an intraoral curve incision of $3 \mathrm{~cm}$. (Figure 7).

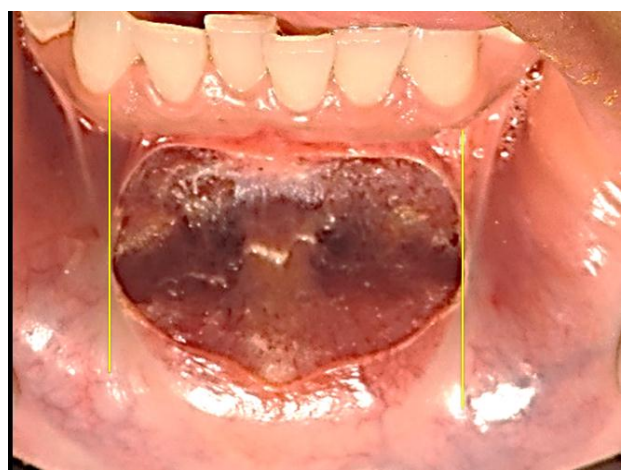

Figure 7. Intraoral curve incision with the distal limit at canine teeth

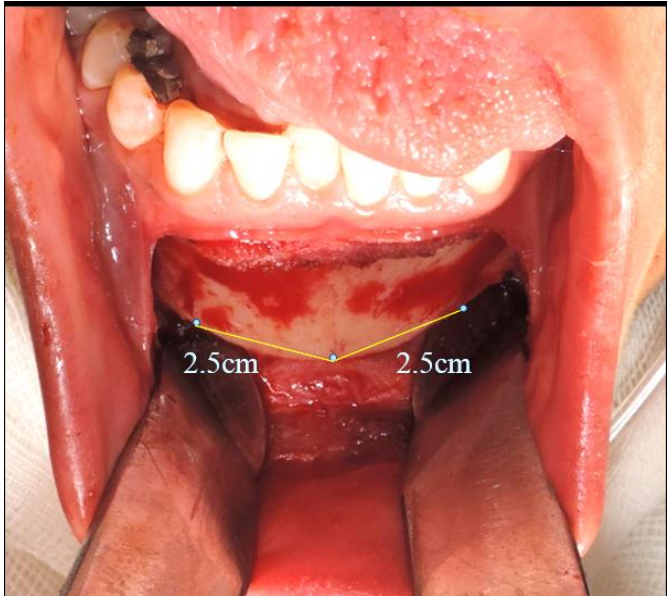

Figure 8. Marking of the distance from the MP and both TPP

The curve osteotomy is designed according to the soft tissue anatomy and the symphysis and parasymphysis anatomy, using as the point of reference the distance from the menton point to the mandibular thinner point (Figure 8 y 9). 


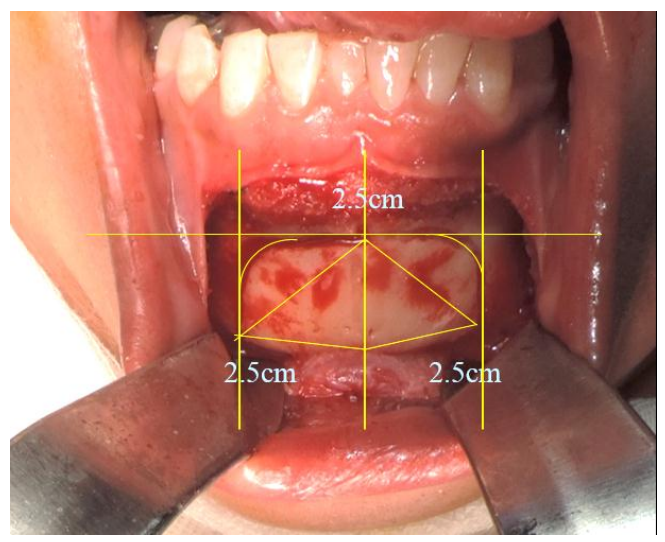

Figure 9. Measurement of distance between the sagittal, transverse and vertical axes.

The next step is to perform the osteotomy with curve external angles until the internal cortical and the advance of the bone segment gently without the mylohyoid muscle dissection and place a rigid fixation plate performed for the chin. (Figures 10 and 11).

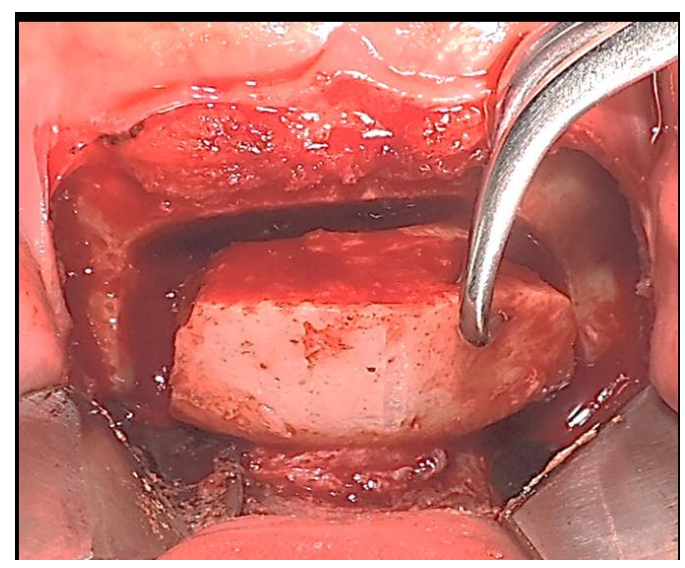

Figure 10. Bone segment advance of $6 \mathrm{~mm}$ according to the surgical plan.

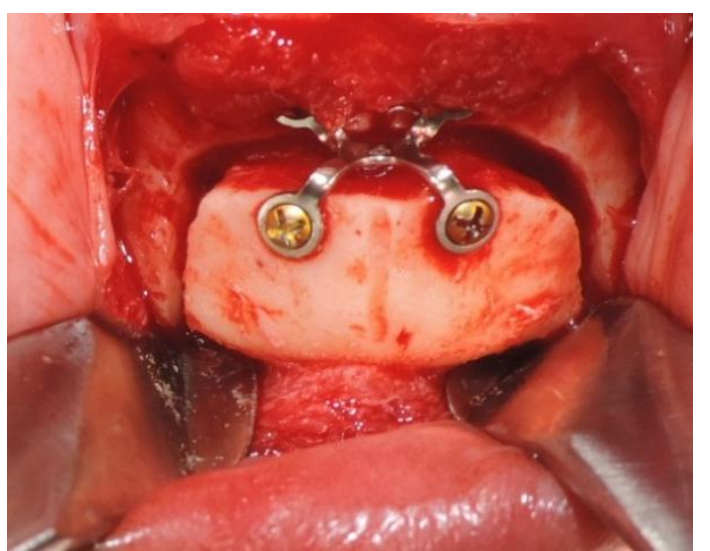

Figure 11. Fixation of chin with a rigid preformed plate.

After fixation sutures are placed in the muscular and mucous planes. (Figure 12).

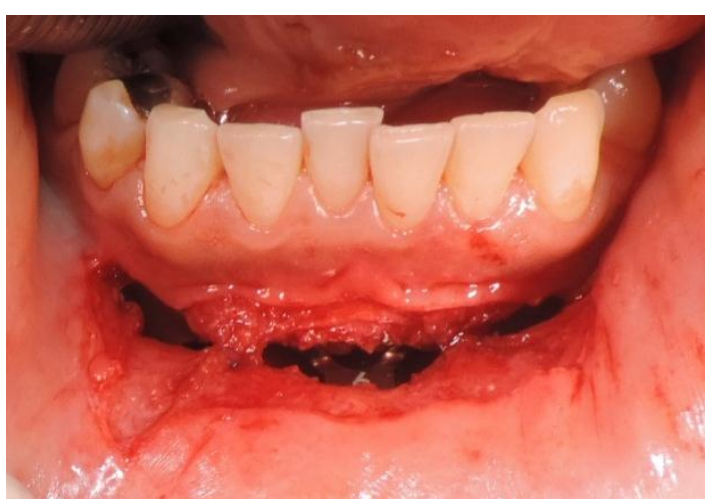

Figure 12. Suture by planes after fixation

The follow up is continued for 6 months with control radiographs and a postsurgical cephalometry as showed in figures 13-16.

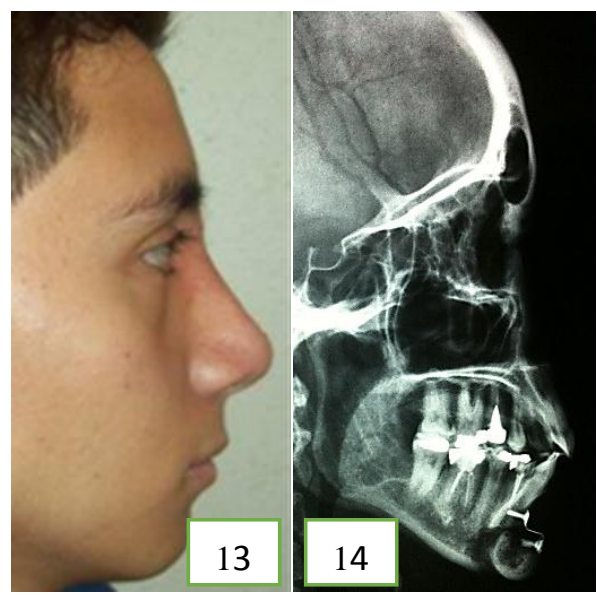

Figures $13 \&$ 14. The final aspect of lateral view and lateral radiograph
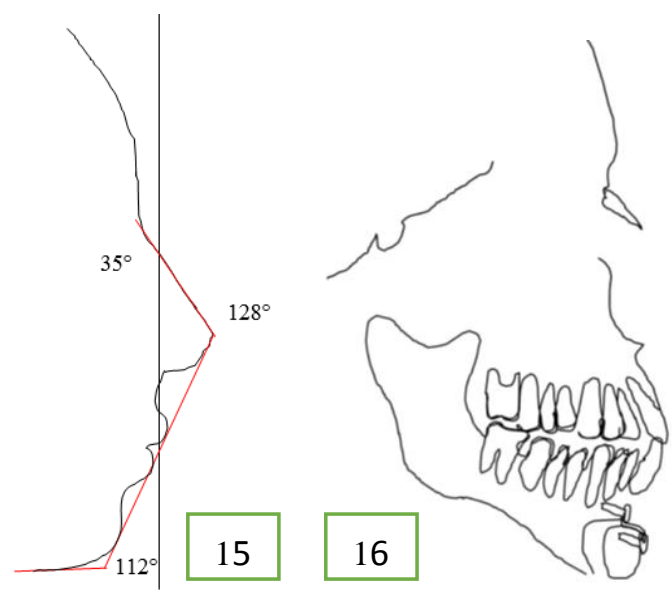

Figure 15 \& 16. Lateral cephalometry of soft and hard tissues

\section{MATERIALS AND METHODS}

For this case series 7 patients were included, four males and 3 females, all between the second and third decade of life with a median age of 35 years old and a mode of 28 years with the diagnosis of mild microgeny (3 cases) and moderate 
microgeny (4 cases) from January to March of 2014, with out systemic diseases and without previous surgeries.

As described before, the technique of curve sagittal mentoplasty was performed in every patient. The neurosensorial response was evaluated from the first to sixth month after surgery according to the neurosensorial evaluation test level A,B and C in three aspects: sensibility to touch in the lower limb, beard tassel, inferior mucous of the limb and mandibular rim of the symphysis: the second aspect was the response to thermic stimulus by an essay tube with hot water at $50^{\circ} \mathrm{C}$, and cold water $\left(5^{\circ} \mathrm{C}\right)$; and the third was the motor response after instructions to move the inferior lip and mental muscles. (Table 1)

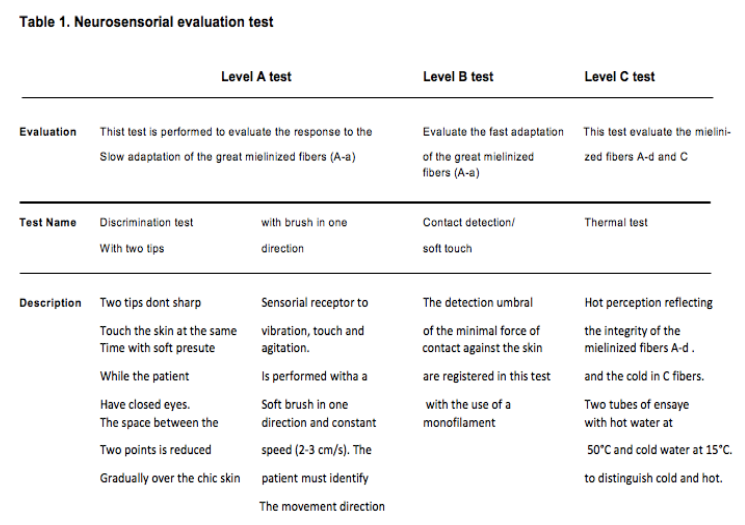

The ordinal punctuation was assigned as follows:

0 - Anesthesia

1 - Level C severe deterioration

2 - Level B moderate deterioration

3 -Level A mild deterioration

4 - Normal neurosensorial responses.

\section{Results}

The neurosensorial response was evaluated during the six months after surgery.

From the 7 patients in the study, 3 mentions that during the sensibility to touch test, they have a transient neurosensorial deficiency bilaterally, 2 in the right side and 1 in the left side, and these deficiencies improve after the third month after surgery.

During the temperature sensibility test 5 mention a diminished sensibility and 2 mention a normal response at the 2 nd month.

In the motor response test, none of the patients referred abnormal responses (Table 2).

\begin{tabular}{|c|c|c|c|}
\hline Time & $\begin{array}{l}\text { Touch } \\
\text { Sensibility }\end{array}$ & $\begin{array}{l}\text { Response to thermal } \\
\text { stimuli }\end{array}$ & $\begin{array}{c}\text { Response to motor } \\
\text { function }\end{array}$ \\
\hline & G/S/N.P & G/S/N.P & G/S/N.P \\
\hline 1st month & $1 \mathrm{~A} /$ bilateral/3 & $1 \mathrm{~B} / \mathrm{bilateral} / 5$ & $4 C / 7$ \\
\hline 2nd month & 2ARight/1ALeft/2 & $2 B /$ bilateral $/ 3$ & $4 C / 7$ \\
\hline 3rd month & 2A Right/1A Left/2 & 3B/Right/2 & $4 C / 7$ \\
\hline 4th month & 3A bilateral/1 & 3B/Right/1 & $4 C / 7$ \\
\hline 5th month & $4 \mathrm{~A} / 7$ & $48 / 7$ & \\
\hline 6th month & $4 \mathrm{~A} / 7$ & $4 B / 7$ & \\
\hline
\end{tabular}

\section{DISCUSSION}

The technique of sliding horizontal mentoplasty described by Hofer in 1942, mentions that the incision must be long enough to observe the mental nerve, the dissection must be until the mental prominence and the extension of the osteotomy must be at the level of the first molar, and although this technique has been modified in several locations the incidence of neurosensorial deficits is very high by the soft tissue manipulation and the muscular desinsertion. ${ }^{2,3,4}$

The curve sagittal mentoplasty is another option in the treatment for mild to moderate microgenia, and this technique, with manipulation ahead of the mental nerve and do not requiring mylohyoid muscle disinsertion, diminish the risk for neurosensorial complications in the soft tissue, with excellent functional and esthetic results ${ }^{1,4}$

\section{Conclusions}

The changes in the neurosensorial response after a mentoplasty could result in a mild sensibility deficit (hypoesthesia) or complete loss of sensibility (anesthesia). Those sensitive deficits could be transient or permanent. Some patients could have dysesthesias, characterized by painful and abnormal sensations. ${ }^{5,6,7}$

For the evaluation of neurosensorial deficits, is important to apply objective tests and do not apply some other subjective tests. The objective data could be acquired from neurosensorial clinical essays or electrophysiologic essays. ${ }^{8-12}$

The curve sagittal osteotomy diminishes neurosensory complications in a significant manner because is designed according to the chin anatomy using as the point of reference the thickness of the mandibular ridge, the incision is smaller, the manipulation ahead of the nerve and do not require the mylohyoid muscle disinsertion.

In this article, we evaluate the neurosensory response after curve sagittal mentoplasty finding 
an improvement in sensibility and motor deficits at third month, and satisfaction with the esthetic results of the surgery in $100 \%$ of the cases.

\section{REFERENCES}

[1] Wang J. Gui L. Xu Q. Cai J. The Sagittal Curving Osteotomy: A modified technique for advanced genioplasty. Journal of Plastic, Reconstructive and Aesthetic Surgery. (2007) 60, 119-124.

[2] Hinds EC, Kent, JN. Genioplasty: the versatility of horizontal osteotomy. J Oral Surg 1969;27: 690-700.

[3] Wolford LM, Bates JD. Surgical Modification for the correction of chin deformities. J Oral Surg 1988; 66:279-86.

[4] Thomson ER. Sagittal genioplasty: a new technique of genioplasty. Br J Plast Surg. 1985; 38: 70-4.

[5] Nishioka GJ, Mason M, Van Sickels JE. Neurosensory disturbance associated with the anterior mandibular horizontal osteotomy. J Oral Maxillofac Surg 1988;46: 107-10.

[6] Laurent G, Walid L, Olivier R. Alteration of chin sensibility due to damage of the cutaneous branch of the mylohyoid nerve during genioplasty. J Oral Maxillofac Surg 2002; 60: 1371-3.

[7] Westermark A, Bystedt H, von Konow L. Inferior alveolar nerve function after mandibular osteotomies. Br J Oral Maxillofac Surg 1998;36:425

[8] Goracy ES. Fracture of the mandibular body and ramus during horizontal osteotomy for augmentation genioplasty. J Oral Surg 1978;36:893

[9] Paul C, James A, David S. Advancement genioplasty with and without soft tissue pedicle: an experimental investigation. J Oral Maxillofac Surg 1984;42:637.

[10] Zuniga JR, Essick GK. A contemporary approach to the clinical evaluation of trigeminal nerve injuries. Oral Maxillofac Clin North Am. $1992 ; 4(2): 353-7$.

[11] Ghali GE, Epker BN. Clinical neurosensory testing: practical applications. J Oral Maxillofac Surg. 1989 Oct;47(10):1074-8.

[12] Preethi Bhat, K. M. Cariappa. Inferior Alveolar Nerve Deficits and Recovery Following Surgical Removal of Impacted Mandibular Third Molars. J. Maxillofac. Oral Surg. (JulySept 2012) 11(3):304-308.

Citation: Mastranzo Corona Héctor et al. Curve Sagittal Mentoplasty, Description of the Technique and Evaluation of the Neurosensory Response. Case Series. ARC Journal of Surgery.2018;4(2) :13-17. doi: dx.doi.org/ 10.20431/2455-572X. 0402003.

Copyright: () 2018 Authors. This is an open-access article distributed under the terms of the Creative Commons Attribution License, which permits unrestricted use, distribution, and reproduction in any medium, provided the original author and source are credited. 